\title{
The Relation Between Corporate Philanthropy and Territorial Development in Brazil: Mapping the Corporate Social Managers' Perspectives
}

Menezes Pagotto, Livia; Xavier Nicolletti, Mariana; Monzoni, Mario

The Relation Between Corporate Philanthropy and Territorial Development in Brazil: Mapping the Corporate Social Managers' Perspectives

Administração Pública e Gestão Social, vol. 14, núm. 1, 2022

Universidade Federal de Viçosa, Brasil

Disponible en: https://www.redalyc.org/articulo.oa?id=351569604004

\section{(C) $(1) \Theta$}

Esta obra está bajo una Licencia Creative Commons Atribución-NoComercial-SinDerivar 4.0 Internacional. 


\title{
The Relation Between Corporate Philanthropy and Territorial Development in Brazil: Mapping the Corporate Social Managers' Perspectives
}

\author{
A Relação entre Filantropia Empresarial e Desenvolvimento Territorial no Brasil: Um Mapeamento das Perspectivas \\ dos Gestores Sociais Corporativos \\ La Relación entre la Filantropía Empresarial y Desarrollo Territorial en el Brasil: Mapeo de las Perspectivas de los \\ Gestores Sociales Corporativos
}

Livia Menezes Pagotto

Fundação Getulio Vargas, Brasil

liviapagotto@gmail.com

Mariana Xavier Nicolletti

Fundação Getulio Vargas, Brasil

mariana.nicolletti@fgv.br

Mario Monzoni

Fundação Getulio Vargas, Brasil

mario.monzoni@fgv.br
Redalyc: https://www.redalyc.org/articulo.oa? id $=351569604004$

Recepción: 20 Enero 2021

Aprobación: 07 Junio 2021

Publicación: 08 Enero 2022

\section{Abstract:}

Research objective: To discuss the relation between corporate philanthropy (CP) and territorial development approach to CP in Brazil from the corporate social managers perspectives.

Theoretical framework: Corporate philanthropy and corporate community relations.

Methodology: Narrative approach based on a two-fold data collection strategy: semi-structured 13 interviews and a focus group with 13 social managers with corporate social managers of large companies, foundations and institutes from different Brazilian regions.

Results: Three main perspectives of corporate social managers make sense of the role of corporate social investment in fostering territorial development: (i) institutional capabilities and social participation; (ii) and aligning of corporate social investment to public policies; and (iii) shared value and social license to operate.

Originality: A comprehensive understanding of the territorial approach for development projects implemented by corporate social managers in Brazil.

Theoretical and practical contributions: Contributions to the literature about corporate philanthropy, corporate community relations and, about the territorial development agenda in Brazil. Practical implications on the roles and responsibilities of businesses and its impacts on territorial development and, on the other hand, of the corporate social manager and its contribution to the development of the localities where a company operates.

KEYWORDS: corporate community relations, narrative analysis, corporate philanthropy, territorial development.

\section{Resumo:}

Objetivo da pesquisa: Discutir a relação entre filantropia empresarial e a abordagem de desenvolvimento territorial aplicada ao investimento social corporativo no Brasil, pela perspectiva dos gestores sociais corporativos.

Marco teórico: Filantropia corporativa e relações comunitárias corporativas.

Metodologia: Abordagem narrativa baseada em uma dupla estratégia de coleta de dados: 13 entrevistas semiestruturadas e grupo focal com 13 gestores sociais corporativos de grandes empresas, fundações e institutos de diferentes regiões brasileiras.

Resultados: Três perspectivas dos gestores sociais corporativos conferem sentido ao papel do investimento social corporativo na promoção do desenvolvimento territorial: (i) capacidades institucionais e participação social; (ii) e alinhamento do investimento social corporativo às políticas públicas; e (iii) valor compartilhado e licença social para operar. 
Originalidade: Uma compreensão abrangente da abordagem territorial para projetos de desenvolvimento implementados por investidores sociais corporativos no Brasil.

Contribuições teóricas e práticas: Contribuições para a literatura sobre filantropia corporativa, relações comunitárias corporativas e sobre a agenda de desenvolvimento territorial no Brasil. Implicações práticas sobre os papéis e responsabilidades das empresas e seus impactos no desenvolvimento territorial e, por outro lado, do investidor social corporativo e sua contribuição para o desenvolvimento das localidades onde uma empresa atua.

Palavras-CHAVE: análise narrativa, desenvolvimento territorial, filantropia empresarial, relações corporativas comunitárias.

\section{ReSUMEN:}

Objetivo de la investigación: Discutir la relación entre filantropía empresarial y la abordagem de desarrollo territorial aplicada a la inversión social corporativa en el Brasil, desde la perspectiva de gestores sociales corporativos

Marco teórico: Filantropía corporativa y relaciones comunitarias corporativas.

Metodología: Enfoque narrativo basado en una doble estrategia de recopilación de datos: 13 entrevistas semiestructuradas y grupo de discusión con 13 gestores sociales corporativos de grandes empresas, fundaciones e institutos de distintas regiones de Brasil.

Resultados: Desde la tres perspectivas dos gestores sociales corporativos confieren sentido al papel de la inversión social corporativa en la promoción del desarrollo territorial: i) las capacidades institucionales y la participación social; ii) y la alineación de la inversión social corporativa con las políticas públicas; y iii) el valor compartido y la licencia social para operar.

Originalidad: Una comprensión integral del enfoque territorial de los proyectos de desarrollo implementados por los inversores sociales corporativos en el Brasil.

Aportaciones teóricas y prácticas: Aportaciones a la literatura sobre filantropía corporativa, relaciones comunitarias corporativas y la agenda de desarrollo territorial en el Brasil. Implicaciones prácticas sobre las funciones y responsabilidades de las empresas y sus repercusiones en el desarrollo territorial y, por otra parte, sobre el inversor social corporativo y su contribución al desarrollo de las localidades en las que opera una empresa.

Palabras Clave: análisis narrativo, desarrollo territorial, filantropía corporativa, relaciones comunitarias corporativas.

\section{INTRODUCTION}

In the past decades, corporate philanthropy (CP) has gained relevance as large companies, with great level of influence in the development paths of the localities where they operate, base their social agendas upon this concept. CP (commonly referred in Brazil as corporate social investment) has been a significant source for social investments in the country: the more than 300 companies and business foundations covered by the report Benchmarking of Corporate Social Investment (BISC) invested approximately US\$ 454 million in 2019 (Comunitas, 2020). CP has been generally associated with community relationships, while corporate social responsibility (CSR) is more related to the interface with other business's stakeholders (Garriga \& Melé, 2004).

Built upon the differentiation from CSR, CP is defined in Brazil as the "voluntary transfer of private resources in a planned, monitored and systematic way for social, environmental and cultural projects of public interest" (GIFE, 2020). It emerged as a category of corporate social action in the 1990s (Nogueira \& Schommer, 2009; Oliva, 2016) and includes all financial resources, goods and services destined by companies to projects and activities of social interest (Comunitas, 2019). During the last three decades, this type of investment has been carved by the practice of the private organizations and its identity increasingly shaped by incorporating management tools, professionalizing both the leading and technical staff, and seeking efficiency and greater impact on investments. Hence, there is a CP culture being strengthened in Brazil based on the efforts to plan, to design actions upon structured strategies, and to monitor and evaluate the results of the investments (Degenszajn \& Ribeiro, 2013).

Regarding the relationship between social investment and business activities, it is possible to identify three main CP phases in Brazil. Before the 1990s, philanthropy was a synonym of assistentialist practices with no orientation towards planned, monitored and systematic results. From the 1990s to early 2000s, the independence of CP's projects decision-making and execution from the sponsor company was a flag. 
After that, the increasing pressure from society for transparency and social control over the corporations' performances propelled the communication of social investment linked to the business. From 2005 on, there is a trend to straighten the corporate institutes and foundations to the companies' social responsibility practices, as well as to influence these organizations with the perspectives and interests of the businesses' top management.

More recently, new trends have marked the CP agenda: the alignment between corporate social investment and business practices, the alignment of this type of investments with public policies, and the focus on community relationships in locations around the corporate operations (Comunitas, 2020; Oliva, 2016; Pagotto et al., 2016). Another CP trend relates to territorial development, which is often associated with corporate community relations (CCR), and mainly targeting education, infrastructure and income generation projects based on a communitarian approach (Comunitas, 2020).

Despite the dissemination of CP practices in the last years in Brazil, the national literature is restricted to the historical perspective (Nogueira \& Schommer, 2009; Rossetti, 2010), to the analysis of challenges, potentialities and tendencies of the agenda (Cabral, 2013; Lessa \& Rossetti, 2016), and to the systematization of experiences and investments over time (Comunitas, 2019; GIFE, 2019). Also, the incorporation of a territorial approach for social investment projects has not been properly discussed so far either by its practitioners or scholars (Harrow \& Jung, 2016). There is a lack of academic research (Nogueira \& Schommer, 2009) and empirical debate on the meanings that the stakeholders, including the sponsor company, confer to CP aimed at collaborating to territorial development.

This paper aims at discussing the relation between $\mathrm{CP}$ and territorial development in Brazil from the corporate social managers perspectives. Considering the other current trends in corporate social investment - especially its alignment with core business - this article seeks to explore the extent of the sound appropriation of the territorial development approach as the focus of social actions by companies, institutes and foundations. In this way, it contributes to advance the understanding of the meanings and potential consequences of large companies incorporating the territorial approach in their social investments.

Our interest lies over the corporate investment operated by companies either through their business units or through corporate foundations and institutes, using private or public (fiscal incentive) resources. For this purpose, we reviewed the literature, conducted a focus group and semi-structured interviews with corporate social managers of large companies, foundations and institutes from different Brazilian regions.

The following sessions present the theoretical debate about CP, territorial development and corporate community relations; the data collected, analysed and findings from the interviews in dialogue with the literature; and the limitations and main contributions of the research.

\section{CORPORATE PHILANTHROPY AND CORPORATE COMMUNITY RELATIONS}

The concept can be characterized as a multifaceted, multi-stakeholder phenomenon whose drivers and outcomes are difficult to measure (Wood \& Jones, 1995). CP is also described as voluntary donations of corporate resources to charitable causes (Gautier \& Pache, 2013). Another interpretation explains CP as a non-obligatory and voluntary transfer of wealth or resources from the firm to outside entities (Saiia et al., 2003), or a common business practice involving voluntary, nonreciprocal transfer of goods (such as money, services etc.) from a corporation to another entity (Hadani \& Coombes, 2015).

CP is considered an important aspect of CSR (Hadani \& Coombes, 2015). Research has been exploring CP from various approaches, for instance: (i) the impact of CP on financial performance (Hadani \& Coombes, 2015; Hogarth et al., 2016); (ii) the impact of CP on reputation for corporate social performance (Gardberg et al., 2017); (iii) corporate motivations for and consumer/public perceptions of corporate giving (Edwards, 2015); (iv) external pressures that drive corporate conduct (Brammer \& Millington, 2005); (v) CP as a crucial element in corporate citizenship (Saiia et al., 2003). 
CP is generally oriented by three main rationales, ranging from most altruistic to most profit-oriented (Gautier \& Pache, 2013). Firstly, CP can be explained as a voluntary expression of the company's commitment to the common good. Secondly, CP may be a long-term community-oriented investment through which companies ensure their competitiveness while fostering their business environment. Thirdly, $\mathrm{CP}$ relates to a marketing strategy, where the philanthropic act of giving is used as a commercial tool (Gautier \& Pache, 2013; Hadani \& Coombes, 2015; Sasse \& Trahan, 2007).

Strategic philanthropy (SP) gained strength from the 2000s on based on a dual objective: benefiting social welfare and financial profitability (Brammer et al. 2006; Bruch \& Walter, 2005; Hemphill, 1999; Porter \& Kramer, 2002; Saiia et al., 2003; Vveinhardt \& Zygmantaite, 2015). Thus, as opposed to an altruistic behaviour, SP seeks to benefit the community but also the firm (Gautier \& Pache, 2013; Saiia et al., 2003). In short, SP projects are strategically motivated giving that they produce a more specific, more measurable benefit in a relatively short-time period, and are focused on motivation, outcomes, implementation strategies, measuring benefit and impact and professional management (Liket \& Maas, 2015; Saiia et al., 2003; Vveinhardt \& Zygmantaite, 2015).

\subsection{Corporate community relations}

CP is a part of corporate citizenship (CC) scholarship and both belong to the CSR literature (Dahlsrud, 2008; Logsdon \& Wood, 2002; Matten \& Crane, 2005; Moon et al., 2005; Sasse \& Trahan, 2007; Vveinhardt \& Zygmantaite, 2015). As CC highlights the importance of a company's social contribution through community or social philanthropic programs, corporate community relations (CCR) acquires a prominent role within this literature body as the communities where corporations are installed are the most commonly partners and stakeholders in corporate citizenship programs (Altman, 1998; Hess, 2002; Seitanidi \& Ryan, 2007; Van der Voort et al., 2009; Waddock \& Boyle, 1995). Consequently, the terms community relations and corporate citizenship are often used interchangeably (Altman, 1998).

CCR evolved to local projects to improve living conditions of communities where the firm was based (Brammer \& Millington, 2005; Gautier \& Pache, 2013; Kasper \& Fulton, 2006), often playing a role of mitigating negative impacts of firms' off-shoring and outsourcing activities (Kasper \& Fulton, 2006). Later, the interactions between firms and communities were pointed out as a driver of CP from the perspective that business competitive advantage is gained by means of improving the local environment where the companies operate (infrastructure, markets, suppliers and others) and enabling local cluster development (Porter \& Kramer, 2002; 2011).

The geographical aspect is fundamental for CCR research. The locus (i.e., the physical place where a company's activities occur, such as a headquarters' office, a store, and a factory) and/or natural resources are explored in order to reveal how they can improve a firm's internal capabilities and enhance its resources, influence local public officers' constituents and contribute to the development of human and organizational capital (Rehbein \& Schuler, 2013).

CCR is "a boundary-spanning corporate function that typically encompasses corporate practices that enable the company to form (hopefully positive) relationships with members of communities in which it operates or with which it has relationships, and with 'society' at various levels" (Waddock, 2008:54) and it includes "specific functions such as a foundation or philanthropic program (corporate philanthropy), volunteer activities, in-kind giving, and multi- or intersectoral partnerships and collaborations for social benefit" (Waddock, 2008:54-55). 


\section{TERRITORIAL DEVELOPMENT}

Since the 1970s, the concept of territory has gained ground in the areas of Geography, Anthropology, International Relations and Political Science. Some fields, such as Sociology and Public Administration, affirm the territorial approach to development to be one of the main innovations in public policy in the 2000s in Brazil and Latin America (Favareto \& Lotta, 2017). From a Human Geography perspective, territorialization implies the rooting and identification of a group, organization or individual with a territory, both in political, economic, more material terms, and in cultural and symbolic terms, strongly immaterial (Haesbaert, 2007). More than political-administrative divisions, a territory is a result of the many power relations, considering both material and symbolic power, as well as of space-time interaction. In this way, a territory is configured by the historical, cultural, political and economic actions of the many actors that live, transit in, make sense of and transform the space (Santos, 1996; 2000).

The concept of territorial development is often associated with the potentialities, resources and institutional arrangements created in specific places and regions and with horizontal relations regarding local production and the relations of productive solidarity between agents and cities that make up a region (Fuini, 2014). While local development concerns what happens at a specific location in small scale (municipalities or communities), territorial development pertains to a process of construction of territorialities by local populations in interrelation between themselves and in relation with institutions and organizations that operate in different scales (Torre \& Wallet, 2015) through which greater value is assigned to local features and territorial capital, as well as the common wellbeing.

The territorial approach to CP could be understood as the investment that enters this system, establishing new balances of power and changing the processes of territorialization and the course of territorial development (Sack, 1986 apud Haesbaert, 2007). Hence, the efforts to identify and understand the perspectives that, at the same time, rule and make sense of CP influence over territorial development is intrinsically tied to the reflection on how large companies, and their institutes and foundations, enter the territorial governance and incur in the collective process of definition, transformation and benefiting from the territorial dynamics.

\section{METHODOLOGICAL APPROACH}

This paper adopts the narrative analysis as the method to qualitatively (Chase, 2005) apprehend the interrelations between person (managers interviewed), stories (about CP and territorial development) and organizations (companies, foundations and institutes), placing the speaker in an organizational context (Czarniawska, 1998). Based on a two-fold strategy — a focus group and semi-structured interviews — we elaborate narrative models convening the main elements of the CP in Brazil (Anastasiadis, 2014).

Narrative is considered as a story containing a plot and coherence between the incidents and events (Boje, 2001). It can also be understood as a "logical, and sometimes causal, chaining of discontinuous unities" (Todorov, 1980 apud Alves \& Blikstein, 2010:5). The discourse (or the sequence of phrases that makes sense upon the combination of linguistic elements) is the narrative basis, the means by which the content is transmitted. In its turn, the narrative is the way through which the past events are combined between themselves and to the present ones (Alves \& Blikstein, 2010). The narrative analysis builds upon the "inscriptions of past performances and scripts and staging instructions for future performances" (Czarniawska, 1998:20).

Based on this approach, CP's territorial dimension is the research focus to be developed through the stories stitched by narrators sitting in corporate positions. They replicate the organizations' strategic communication (Alves \& Blikstein, 2010; Boje 2001; Bryman, 2012; Czarniawska 1998) and, at the same time, reflect on the narratives, inserting elements, selecting the excerpts that deserve to be told, synthesizing 
meanings and transforming some intermediary messages in a dialogue between structure and agency, organizational culture and individual repertory.

The interviewers fostered a retrospective sense-making (Chase, 2005), starting from the conception of the $\mathrm{CP}$, covering the organizational transformations, practices, stakeholders involved, results achieved, and current initiatives. We worked on the functions (actions) present in the narratives and on the indications of feelings, philosophies, beliefs that support the stories as they were told.

\subsection{Data collection}

We collected data following a two-fold strategy: focus group and semi-structured interviews. The unit of analysis is the corporate social managers responsible for implementing projects focused on territorial and/ or local development in Brazil.

First, we conducted a focus group with 13 Brazilian corporate social managers from ten companies belonging to seven different sectors (Table 1). According to Bloor and colleagues, "focus groups can be used for the generation of information on collective views", but also "will provide rich data on the group meanings associated with a given issue" (2002:4). Focus groups emphasize a specific theme or topic and the ways in which individuals discuss a certain issue as members of aroup (Bryman, 2012). We facilitated the discussion that lasted three hours and 30 minutes.

TABLE 1

Detailed overview of the focus group's participants

\begin{tabular}{lll}
\hline Company's main sector & N. of participants & Participant(S) position \\
\hline Construction & 2 & Manager; Specialist (Sustainability department) \\
Energy & 1 & Analyst (Sustainability department) \\
Agribusiness & 1 & Analyst (Sustainability department) \\
Telecom & 2 & Analyst; Assistant (Foundation) \\
Agribusiness & 2 & Director; Manager (Foundation) \\
Third sector* & 1 & Coordinator \\
Agribusiness & 1 & Coordinator (Foundation) \\
Construction & 1 & Manager (Institute) \\
Petrochemical Banking & 11 & Coordinator (Social Responsibility Department) \\
& & Coordinator (Sustainability department) \\
\hline
\end{tabular}

\footnotetext{
* A representative of one of the largest Brazilian associations bringing together corporate social managers was invited to the focus group given his prior knowledge and a comprehensive vision of the sector
}

We based the focus group's facilitation on the Iceberg model as a methodological procedure, which provides the emergence of systemic thinking by looking at four dimensions: events, patterns and trends, structures and mental models. The model is used to visualize what is happening about a phenomenon, as well as the different institutions and influences that led to the situation (Goodman, 2002).

We considered the Iceberg model as a suitable procedure for the focus group due its capacity to incorporate a systems perspective, which is important to frame questions and make sense out of qualitative data (Patton, 2001). In total, 13 one-to-one semi-structured interviews were carried out with corporate social managers (Table 2). The interviews lasted between 40 minutes and one hour and 26 minutes and were conducted in Portuguese, audio-recorded and transcribed. 
TABLE 2

Detailed overview of the semi structured interviews' participants

\begin{tabular}{lll}
\hline Sector & Position & Duration \\
\hline Paper Pulp & Analyst; Intern; Intern (Sustainability & $00: 54: 46$ (in person) \\
department) & $00: 52: 05$ (Skype) \\
Mining & Analyst (Institute) & $00: 45: 28$ (Skype) \\
Mining & Manager (Sustainability department) & $00: 40: 31$ (in person) \\
Health care & Director (Institute) & $01: 08: 10$ (in person) \\
Mining & Manager (Institute) & $01: 26: 09$ (in person) \\
Steel Mining & Director (Foundation) & $00: 50: 17$ (in person) \\
Paper Pulp & Director (Foundation) & $00: 45: 32$ (in person) \\
Engineering Construction & Manager; Analyst (Sustainability & \\
Agribusiness & department) & $00: 55: 31$ (in person) \\
Mining & Director (Institute) & $01: 08: 17$ (in person) \\
Construction Agribusiness & Director; Coordinator (Foundation) & $01: 25: 35$ (in person) \\
Food & Director; Coordinator (Institute) & $00: 59: 05$ (Skype) \\
Wood products & Superintendent; Legal director & \\
& (Foundation) & $00: 50: 48$ (in person) \\
& Manager; Analyst (Institute) & $00: 46: 18$ (in person) \\
\hline
\end{tabular}

For both the focus group and the semi-structured interviews, the participants were invited based on the identification of companies that publicly declare to develop corporate social investment of territorial type on the following Brazilian databases: (i) Corporate Sustainability Index (ISE); (ii) Exame Sustainability Guide; and (iii) Group of Institutes, Foundations and Enterprises (GIFE) (a non-profit organization that is the major Brazilian reference in the field of corporate social investment). For participating in the focus group, 46 invitations were sent and the authors received 13 acceptances. As for the semi-structured interviews, 22 invitations were sent and the authors received 13 acceptances. Two participants were present at both events.

\subsection{Data analysis procedures}

The results obtained in the focus group guided the semi-structured interviews' questionnaire development. By drawing on the group's responses to the events, patterns and trends, structures, and mental models (focus group guidelines) related to CP's territorial dimension, questions were elaborated to further investigate this kind of corporate social investment features in Brazil through the interviews. Thus, the semi-structured interviews guidelines reflect the issues that emerged as determinant for understanding the CP in Brazil and its relation to territorial development and should be explored based on each corporate social manager experience. The interviewees' answers, in turn, derived the categories of analysis used to identify the narratives used by corporate social managers to make sense of their CP's territorial strategies. Thus, the categories of analysis were formulated and revised through an iterative process as the results of the focus group and interviews were interpreted. Table 3 synthesizes the components of the Iceberg model, explored in the focus group, the elements further investigated in the semi-structured interviews and the resulting categories of analysis. 
TABLE 3

Synthesis of focus group and semistructured interviews' guidelines and categories of analysis

\begin{tabular}{lll}
\hline Focus group guideline & Semi-structured interviews guideline & Categories of analysis \\
\hline Events & Characterization of the strategy of action & $\begin{array}{l}\text { Semantics of territorial } \\
\text { development }\end{array}$ \\
Structures & $\begin{array}{l}\text { Understanding on territorial } \\
\text { development }\end{array}$ & Capabilities \\
Mental model & Objectives and motivations & Participation \\
& Territory definition criteria & Communities empowerment \\
& Public interest definition & Role of the state \\
& Role of corporate social managers \\
& Shared value \\
& Social license to operate \\
& Public interest
\end{tabular}

Nine analytical categories were identified based on central ideas that emerged from the narratives extracted from both the focus group and the interviews: either because they are common to various speeches, or because they present central ideas that stand out in relation to the topic explored here. Accordingly, the narratives drawn in this research resound individual-collective understandings of the involved corporate social managers on strategy of action, territorial development, objectives and motivations, decision-making criteria and public interest.

\section{FINDINGS}

This section starts by discussing the corporate social managers' view on territorial development. It then turns to assembling their three major perspectives to make sense of their practices considering the territorial dimension of philanthropy in Brazil.

\subsection{Corporate social managers' view on territorial development}

Overall, the designation of an approach that considers the territory as a reference for corporate social investment is associated with four correlated terms: territorial development, local development, community development, and regional sustainable development. The same organization or even the same interviewee uses these terms interchangeably. One interviewee said: "It's kind of confusing. We use community development, local development, territorial development".

Despite the lack of conceptual accuracy, there is a set of common understandings among the interviewees about the practice of territorial development as the focus of CP initiatives in Brazil. First, they share a vision that this kind of social investment is a contribution to the common good and it represents a corporate legacy to it, guided by the intention of building a sound, comprehensive, long-term and participative local agenda. "Our focus is social, the goal is not to potentiate the company's brand, but to leave a public legacy", said one of the interviewee. Another interviewee mentioned: "What we want is to leave a legacy, we need to improve 
the lives of these people. The company has a responsibility to the society that receives it and that starts to enjoy everything in the region".

Second, two statements illustrate local protagonism as another point of convergence: "the perspective of network strengthening was a radical change in our approach, meaning to support the community leaders and generating results that foster the independence of this network in relation to the Institute"; and "we've learned that philanthropy and assistance are important, but an approach driven to enhancing the community's protagonism is crucial". By local protagonism the interviewees refer to the extent of the communities' independence of the company's presence and actions and, mainly, the empowerment process undertaken by the local communities in shaping a territorial development agenda. It is worth noting that when mentioning the institutes and foundations, the corporate social managers refers to the social arm of corporations which are in great part funded by the latter ones and have their actuation increasingly aligned to business focuses and interests (according to the tendency of alignment between the social investment and the core business).

The extent of endogeneity for the social projects' development also varies among the interviewees and the focus group's participants, which makes the third common understanding: on the one hand, the initiatives might be associated with local networks that draw and implement the actions hand in hand with the company's support; on the other hand, the company may perform a peripheral role in the social investment strategy. One interviewee stated: "Community development was the most assertive strategy, as we began the process of this transformation, of this intervention, from the beginning with the participation of the community, and not with something ready, pre-formatted". This variation relates to the corporate social manager orientation towards local communities and his/her willingness and trust in an endogenous community process.

Fourth, throughout the process of promoting social transformation and leaving a local legacy through territorial development projects where companies operate, the institutes and foundations assume the management and control of corporate social investment. They declared to employ a range of efforts to ensure that the financial and human resources are driven towards both the benefit of the local society and the company. While in some cases corporate institutes and foundations fully coordinate the social projects' implementation, in other cases the business units (for instance, the CSR or the sustainability area) are in charge of it. In the latter cases, there are experiences integrating the business CSR and the CP's corporate arm (institute or foundation) and others of total disconnection. Ultimately, this is linked to the source and type of the resources invested: there are projects totally funded by the sponsor company, as well as some run with no financial resources from the company. In these latter cases the manager offers technical, infrastructural and institutional support and the financial resources come from partnerships, mainly other social managers.

\subsection{Institutional capabilities and social participation}

Despite the recognition that the experiences, perspectives and meanings of CP are by no means unison, it was possible to identify three transversal macro-narratives on the meaning of corporate social investment based on a territorial approach. The first one regards the historical shift in CP in Brazil and the relevance of considering institutional capabilities and social participation in implementing social projects.

According to the corporate social managers, the results of the last decades of social investment focused on territorial development in Brazil have generated a learning process that indicates the importance of this type of investment in strengthening local institutional capabilities and social participation through local forums for debate and deliberation. This reflection is based on the recognition that short-term action, characteristic of the first philanthropic phase in Brazil (assistentialist), created a dependency of local communities on corporate social investments and minimized the potential benefits for both the communities as well the corporate social managers and their sponsor companies. 
The learning process has contributed to the establishment of a new paradigm of interventions by corporate social managers focused on strengthening local institutional capabilities and local participation processes and forums, as mentioned by one of the interviewees: "We promote business partnerships based on the identification of the municipal capacity to generate income. The company does not aim to be a protagonist, but to enhance local capabilities". With regard to the local institutional capabilities' strengthening process, corporate social managers consider that a comprehensive diagnosis and constant dialogue with local characteristics are fundamental to avoid predefined or pre-formatted models of territorial development. Moreover, they emphasize the relevance of listening to the local community not just when arriving in the territory, but on an on-going basis. One interviewee said: "The social investment is more effective if it complements what already exists in the territory. (...) This is our main learning: the ability to be complementary and this requires skills, presupposes active listening of the territory."

Regarding participatory processes, supporting the creation or strengthening of local social participation forums (e.g. community forums and government councils) is crucial for the appropriation of development processes by local communities and, in addition, to foster the establishment of partnerships between the different social actors of the locality in question. A focus group's participant said: "Specific topics and the project activities are now defined together with the groups. (...) The leap was when leaders entered into the implementation, welcoming and supporting, the autonomy generated openness to mind-set changing. It is a bottom-up movement."

Both elements - strengthening local institutional capabilities and participatory processes and forums - changed the way corporate social managers present themselves before the communities as one more actor responsible for the development of the localities where their sponsor companies operate. From the managers' point of view, it also means decentralizing their own protagonism as the main promoter of territorial development, which generates autonomy for the territories and diminishes the dependence of local development on the social managers contribution of human and financial resources, especially the financial ones. Public interest, which is the cornerstone of corporate social investment, would then be secured through the empowerment and participation of local actors, in addition to strengthening local institutional capabilities, as illustrated by one of the interviewed social managers: "The company aims to contribute to the local social capital by convening partners, strengthening local networks and aligning the initiatives to public policies."

In this scenario of community empowerment, the local networks are exalted as a governance model for territorial development. Numerous social managers defined their way of work as articulators of networks formed by civil society, local government organizations, communities, and businesses, including themselves. And by assuming the position of one more actor in the network, the corporate institutes and foundations lean their structures relying on the local actors as project implementers and partnering with other social managers.

\subsection{Strengthening public administration and aligning corporate social investment to public policies}

The second narrative about the importance of corporate social investment in territorial development projects in the Brazilian context is the historical institutional weaknesses with respect to local public policies and their effectiveness in terms of the local population's well being.

According to the corporate social managers, this is due mainly to the following factors: low qualification of the local civil service; short-term vision by public managers of territorial development given the four-year political cycle in Brazilian municipalities; low administrative capacity to manage the budget increase due to 
business tax collection; and lack of clear definition of roles with respect to the various impacts caused by the businesses activity and the responsibilities of mitigating them.

Even when the social projects do not involve directly the government spheres, it is clear to the managers that the projects' effectiveness depends on the public sector; and to deal with this condition is assumed as one major challenge. As a response to the perception of institutional weaknesses of public institutions at the local level, the corporate social investment focused on territorial development has intensified in the past decade projects aimed at strengthening public management and aligning private projects with local public policies: "We act aiming to tackle bottlenecks in order to allow the local development and take a seat in local councils.", said one of the interviewees.

The belief of corporate social managers is that, besides increasing the communities' quality of life, this approach contributes to the business operation as public policies to contribute to the better preparation of territories to deal with the corporate social, environmental and economic impacts and to generate more opportunities for local development. An interviewee said about this topic: "Working proactively is better than working reactively. The financial gains are very high. If I have a municipality in which the revenue is actually being invested in the municipality, and quality health, I can attract and retain good professionals and their families". Another testimony affirms: "the private performance will always be marginal in relation to the performance and level of investment of the public authority, so actions need to be better integrated with public policies."

Corporate social managers declare to delimit their role in the realm of public administration as a convening power. A focus group's participant describes this role: "I am not, as a company, taking over the role of the State; I am empowering the State to do it." In this way they recognize themselves as stimulators of the State to assume its role and being part of the solution through the process of strengthening local public policies.

\subsection{Shared value and social license to operate: aligning corporate social investment and core business}

The third narrative used by corporate social managers to describe their projects with a territorial approach combines two perspectives: shared value and social license to operate. The latter one is understood as the ongoing acceptance and approval of a company's development and operation by local community members and other stakeholders that can affect its profitability (Moffat \& Zhang, 2014).

The majority of projects are implemented by corporate social managers in localities where the social investment's sponsor companies operate and are under an increasing process of alignment between the social investment and the core business, as presented here: "the social investment is aligned to the business and located in municipalities where the company has its business units." The social managers attribute this movement to the social responsibility of the companies over the development of these territories, especially because most of them are located in small Brazilian municipalities. In this context, corporate social investment and corporate sustainability get closely associated and the combination of pursuing the social license and generating value both for the society and the company is intensified.

These elements, in turn, contribute to other defining aspects of the relationship between the company in charge of implementing the social project and the territory that hosts it. Among them are the company's positive reputation and image before local communities and society as a whole. Also, there is the recognition that more sustainable compliance and risk management processes are acquired as sponsor companies endeavour to minimize conflicts with local communities.

Still in terms of corporate image, the positioning of the social managers as an actor that, in addition to mitigating the operation's impacts, is one of the many actors responsible for territorial development reinforces the legitimacy of corporate social investment and mitigates the eventual dependence of local 
communities on such initiatives. Moreover, obtaining legitimacy of the corporate social investment is equally important as regards the sponsor company's relationship with managers and clients due to commercial and investment protocols and risk management guidelines spread in some sectors.

\section{DISCUSSIONS}

Territorial development - as a trend itself - relates to the other trends previously indicated in this article (the alignment between corporate social investment and business practices, and the alignment of this type of investments with public policies) since it mobilizes a public outlook on the part of the social corporate manager, but still from a private perspective given the trend to align social actions with core business and corporate practices. Taking this into account, this article articulates conceptual and empirical contributions (as presented below).

Overall, it can be said that the empirical phenomenon of territorial approach to corporate social investment in Brazil evokes conceptual aspects mobilized for this article's development, as shown in Figure 1.

Figure 1: Conceptual and empirical definitions of the territorial approach to corporate philanthropy

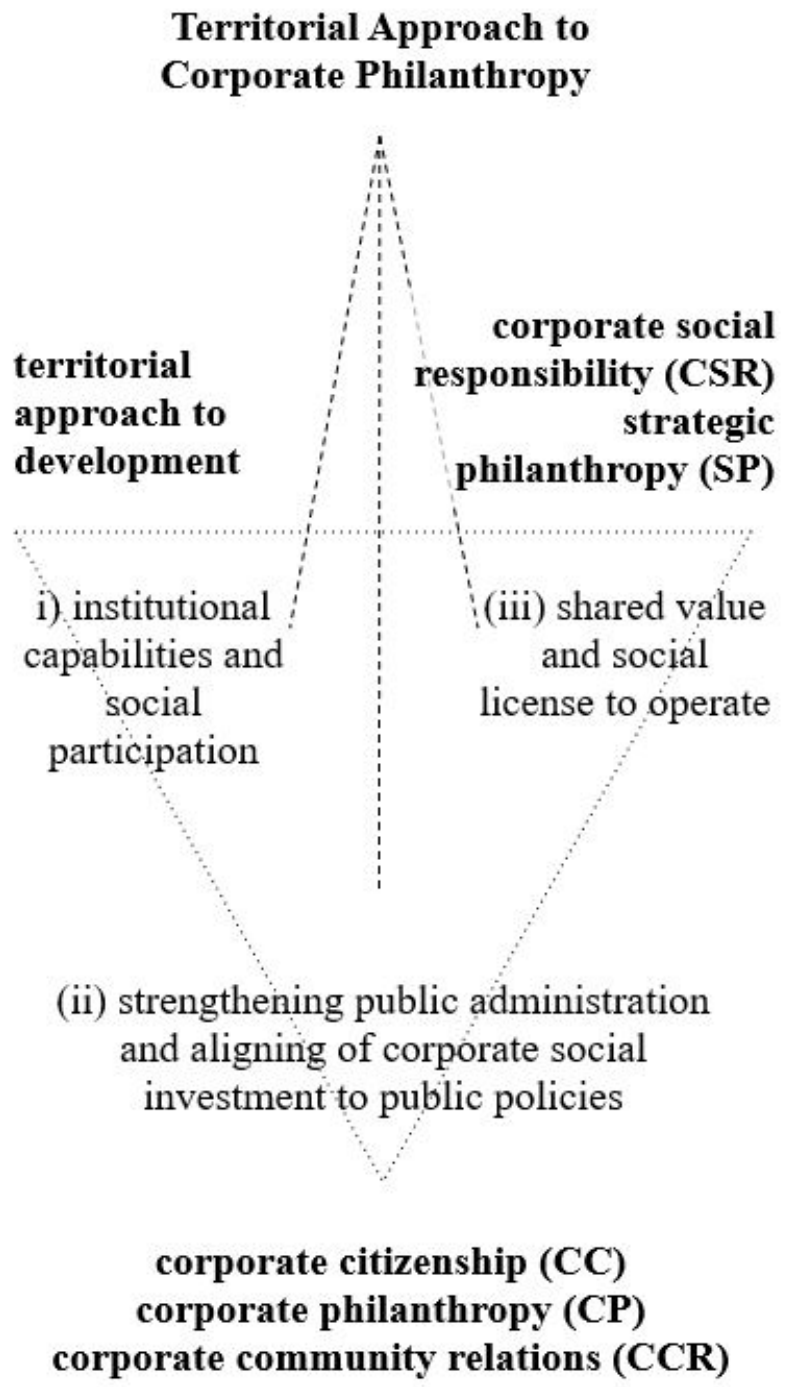


The territorial development approach is the expression of two trends of the CP in Brazil: the alignment between CP and public policies, and the alignment between CP and business practices (Comunitas, 2019; Oliva, 2016; Pagotto et al., 2016). And how come the territorial type of CP has established itself as a trend? Firstly, it takes place in the territories where companies operate and this guarantees the sustainability of corporate institutes and foundations in Brazil, as it is easier to justify to the business as strategic philanthropy (Brammer et al. 2006; Bruch \& Walter, 2005; Hemphill, 1999; Porter \& Kramer, 2002; Saiia et al., 2003; Vveinhardt \& Zygmantaite, 2015). It is worth noting that CP is the predominant agenda of Brazilian philanthropy in terms of the type of social managers and the amount of investments (GIFE, 2018). Secondly, the territorial approach has become a buzzword after decades of its incorporation in early decades in development projects (from the 1970s on), then in public policies (from the 1990s on), until it reaches CP in Brazil in the $21^{\text {st }}$ century (Favareto \& Lotta, 2017). Thirdly, CP of territorial type reflects an attempt to advance development practices in Brazil, looking at rural-urban realities in a more coordinated way based on multi-level and multi-stakeholder governance (Favareto \& Lotta, 2017). Fourthly, it reflects a series of gaps in the reach of the State at the municipal level in Brazil and the institutional weaknesses that the country has in terms of implementing public policies at this administrative level. Nationally, there are many regions still characterized by basic services' deprivation, especially in remote regions, which is mostly where large companies operate.

At the same time, the territorial approach of $\mathrm{CP}$ also reflects the Brazilian political process in the last decades, characterized by the re-democratization begun in the late 1980s. It was based, among other aspects, on political decentralization, participatory democracy, citizen inclusion and political innovation considering reality and local potential (Abrucio, 2007). In parallel, the notion of territorial governance is intensified in the country, based on the assumption of a territorial development vision, interpreted as a spatially coordinated local development that requires the interaction of actors operating at multiple planning and administration scales (Romeo, 2013). It is also used in the context of initiatives or actions that express the capacity of a territorially organized society to manage public affairs from cooperative involvement of social, economic, and institutional actors (Dallabrida, 2011). This multiplicity of relationships and interests is connected to common planning vision, or a shared territorial vision, based on the recognition and valorisation of territorial capital and cohesion at different levels (Davoudi et al., 2008).

The social managers' perspectives also trigger a set of reflections about the next wave of CP focused on territorial development. If the corporate social managers consulted refer to a scenario of historical change in the way they relate to communities and territories (from the assistentialist approach to the need of strengthening of local institutional capacities and participation), we perceive the importance of going beyond the clichés such as "There is no silver bullet." and "Give a man a fish, he eats for a day. Teach a man how to fish, he eats for a lifetime." and to structure a qualified debate in Brazil on CP and territorial development.

In the spirit of the territorial approach to development, it makes sense for corporate social managers to participate and support the development path of the localities in which the respective holding companies operate, even reducing the dependence of such localities on the resources of corporate social managers, in the figure of the sponsor companies or their institutes and foundations. In this context, the manifestation of corporate citizenship and the commitment to the common good (Gautier \& Pache, 2013; Matten \& Crane, 2005; Saiia et al., 2003) are favourable.

In this sense, the inclusion of the territorial notion into the practices of CP brings advances to the field. One of them is the intention, on the part of social managers, to improve their practices when they relate to communities. Acting territorially requires a greater level of sophistication in terms of the social interventions' processes and results in territories throughout Brazil. And this leads, in general, to a process of collective learning and maturation of the CP practices.

Another advance concerns the complexity of today's social challenges and the demand for joint and multidimensional actions. If companies, their institutes and foundations can contribute to the 
implementation of social projects, especially in needy regions, this may represent a hope that other actors can join forces and make actions gain scale by, for example, public policies.

However, a constant critique of CP's limitations of the CP contribution to the local trajectories of territorial development that require autonomy and local participation is necessary. For example, there is no homogeneous understanding of what a territorial approach to development is (Harrow \& Jung, 2016). This means that there can be a misuse of what is truly territorial development by means of rhetorically incorporating this concept into corporate ideological discourse, and that it is easily confused with more simplistic community relations practices (Fuini, 2014; Haesbaert, 2007).

Another limitation is related to the fact that companies, corporate institutes and foundations place themselves as facilitators of the process of territorial development, with possible implications: to generate dependence on the community (even if there is the underlying premise that the company is only a facilitator) whether financial or paternalistically; to have the corporate social investments stopped at any time if the company decides to leave the territory, even if this has not been identified as a risk by the interviewees and the focal group participants carried out for this research; and/or to dictate the paths of the local development due historical and stiffened power relations, for instance based on organizational position, social class or education level, which tend to be replicated in pretended collaborative processes if not explicit considered and addressed by the facilitators.

\section{CONCLUDING REMARKS}

This article provides conceptual and empirical contributions to advancing the understanding of the incorporation of territorial development approach into the social investment strategies of large companies in Brazil. By identifying the perspectives through which the corporate social managers give sense to this approach, this research spots light into some of their potentialities and concerns regarding the territorial development as collective process mediated by power relations, community dependence and social participation, strengthening of public administration and alignment of $\mathrm{CP}$ to public policies and creation of shared value and obtaining social license for the business to operate.

Thus, this article reconciles the literature about corporate philanthropy and corporate community relations, and the territorial development agenda in Brazil. A specific look at this country's perspective on the role of corporate social managers in territorial development exposes the reality faced by an emerging economy in terms of fragilities and gaps of local institutions and governance, but also in terms of the need to improve corporate philanthropy practices and conceptualization.

Researching about CP is a challenging choice within the Brazilian context. The lack of consistent and rigorous research on the strategies and practices of corporate social managers and the current dynamism of corporate giving in the country are some examples of the challenges. At the same time, some recent trends, such as the alignment of CP focused on territorial development between, on one side, to the core business, and, on the other, to public policies, are introducing a favourable and fertile environment for advancing the knowledge available about the meaning and practices of social managers.

The results raise questions about the roles and responsibilities of businesses and its impacts on territorial development and, on the other hand, of the corporate social manager and its contribution to the development of the localities where a company operates. In this sense, the question about the limits of the performance of this type of corporate investment in the field of public policies is also relevant. If, on one hand, it can be positive for the improvement of corporate philanthropy actions and support the long-term initiative (as highlighted by the literature on territorial development), on the other hand, there is a possible confusion between the public and private dimensions.

In this context, further research could add fruitful insights to the role of CP in Brazil in terms of fostering territorial development. An interesting topic that would benefit researchers and policymakers understanding 
on this role includes an in-depth sector analysis of the main raw material industry (forest-based, metal, mineral and non-energy extractive industries, and non-metallic minerals industries), in order to comprehend specifics about the relationship between these type of industries and local communities. Moreover, it would be of great value a comprehensive analysis on the risks, opportunities and effects of the alignment of CP focused on territorial development to (i) core business, and (ii) local public policies as regards to the public interest. Finally, a broader understanding on the meanings of territorial development fostered by corporate social managers would demand a qualitative research approach to local actors, including interviews with civil society, local public administration and company's representatives.

\section{ACKNOWLEDGMENTS}

The research was funded by GVpesquisa.

\section{REFERENCES}

Abramovay, R. (2000). O capital social dos territórios: repensando o desenvolvimento rural. Economia Aplicada, 4(2), 379-397.

Abrucio, F. L. (2007). Trajetória recente da gestão pública brasileira: um balanço crítico e a renovação da agenda de reformas. Revista de Administração Pública, 41(1), 67-86.

Altman, B. W. (1998). Transformed Corporate Community Relations: A Management Tool for Achieving Corporate Citizenship. Business and Society Review, 102(103), 43-51.

Alves, M. A., \& Blikstein, I. (2010). Análise de Narrativas. In C. K. Godoi; R. Bandeira de Melo; A. B. Silva. (eds.). Pesquisa Qualitativa em Estudos Organizacionais: paradigmas, estratégias e métodos (pp. 403-428). São Paulo, Editora Saraiva.

Anastasiadis, S. (2014). Toward a view of citizenship and lobbying: Corporate engagement in the political process. Business \& Society, 53(2), 260-299.

Bloor, M., Frankland, J., Thomas, M., \& Robson, K. (2002). Focus Groups in Social Research. Sage Publications, London.

Boje, D. M. (2001). Narrative Methodsfor Organizational \& Communication Research. New Mexico State University, USA.

Brammer, S., \& Millington, A. (2005). Corporate reputation and philanthropy: An empirical analysis. Journal of Business Ethics, 61(1), 29-44.

Brammer, S., Brooks, C., \& Pavelin, S. (2006). Corporate Social Performance and Stock Returns: UK Evidence from Disaggregate Measures. Financial Management, 35(3), 97-116.

Bryman, A. (2012). Social Research Methods. (4th ed.). Oxford University Press, New York.

Bruch, H., \& Walter, F. (2005). The Keys to Rethinking Corporate Philanthropy. MIT Sloan Management Review, $47,49-55$.

Cabral, M. (2013). Em busca de um lugar. In F. Deboni (eds.), Investimento Social Privado no Brasil: tendências, desafios epotencialidades, (pp. 39-44). Brasília: Instituto Sabin.

Chase, S. E. (2005). Narrative Inquiry. Multiple Lenses, Approaches, Voices. In N. K. Denzin, \& Y. S. Lincoln (Eds.), The Sage Handbook of Qualitative Research (3rd Edition) (pp. 651-679). London, Thousand Oaks, CA, and New Delhi: Sage.

Comunitas (2020). Benchmarking do Investimento Social Corporativo - Relatório 2020. Retrieved January 02, 2021, from https://www.comunitas.org/bisc/.

Czarniawska, F. (1998). A narrative approach in organization studies. Thousand Oaks, California, Sage.

Dahlsrud, A. (2008). How corporate social responsibility is defined: An analysis of 37 definitions. Corporate Social Responsibility and Environmental Management, 15(1), 1-13. 
Dallabrida, V. R. (2011). Governança Territorial e Desenvolvimento: uma introdução ao tema. Governança Territorial e Desenvolvimento: Descentralização Político-Administrativa, Estruturas Subnacionais de Gestão do Desenvolvimento e Capacidades Estatais. (pp. 15-38). Rio de Janeiro: Editora Garamond.

Davoudi, S., Evans, N., Governa, F., \& Santangelo, M. (2008). Territorial governance in the making. Approaches, methodologies, practices. Boletin de la $A G E, 46,3352$.

Degenszajn, A., \& Ribeiro, P. (2013). O investimento social em movimento. In F. Deboni (ed.). Investimento Social Privado no Brasil: tendências, desafios e potencialidades, (pp. 19-30). Brasília: Instituto Sabin.

Edwards, H. (2015). Social responsibility and the evolution of corporate philanthropy: An analysis of successful corporate-cause partnerships in an era of the global corporate citizen. PRism, 12(2), 1-14.

Favareto, A., \& Lotta, G. (2017). Inovac\#o\#es institucionais nas poli\#ticas para o desenvolvimento territorial em tre\#s estados brasileiros. Redes, 22(3), 11-38.

Fontana, A., Sastre-Merino, S. \& Baca, M. (2017). The Territorial Dimension: The Component of Business Strategy that Prevents the Generation of Social Conflicts. Journal of Business Ethics, 141, 367-380.

Fuini, L. L. (2014). A territorializac\# a\#o do desenvolvimento: construindo uma proposta metodolo\#gica. Interações, Campo Grande, 15(1), 21-34.

Gardberg, N. A., Zyglidopoulos, S. C., Symeou, P. C., \& Schepers, D. H. The Impact of Corporate Philanthropy on Reputation for Corporate Social Performance. Business \& Society, 58(6), 1177-1208.

Garriga, E., \& Melé, D. (2004). Corporate social responsibility theories: Mapping the territory. Journal of Business Ethics, 53(1-2), 51-71.

Gautier, A., \& Pache, A-C. (2013). Research on Corporate Philanthropy: A Review and Assessment. Journal Business Ethics, 126, 343-369.

GIFE (2020). Investimento Social Privado. Retrieved February 11, 2020, from https://gife.org.br/investimento-soc ial-privado/.

GIFE (2019). Censo GIFE 2018. Erika Sanchez Saez, Jose\# Marcelo Zacchi, Gustavo Bernardino (orgs.), 1. ed. Sa\#o Paulo: GIFE. Retrieved February 01, 2020, from https://sinapse.gife.org.br/download/censo-gife-2018.

Goodman, M. (2002). The iceberg model. Innovation Associates Organizational Learning. Hopkinton, MA. Retrieved January 30, 2020, from http://www.ascd.org/ASCD/pdf/journals /ed_lead/ el200910_kohm_iceberg.pdf.

Hadani, M., \& Coombes, S. (2015). Complementary Relationships Between Corporate Philanthropy and Corporate Political Activity: An Exploratory Study of Political Marketplace Contingencies. Business \& Society, 54(6), 859-881.

Haesbaert, R. (2007). Território e multiterritorialidade: um debate. GeoGraphia, 9(17), 19-46.

Haesbaert, R. (2012). A Global Sense of Place and Multi - territoriality. Notes for Dialogue from a 'Peripheral' Point of View. In: Featherstone, D., \& Painter, P. Spatial Politics. 20 November 2012.

Harrow, J., \& Jung, T. (2016). Philanthropy and Community Development: the vital signs of community foundations? Community Development Journal, 51(1), 132-152.

Hemphill, T. A. (1999). Corporate Governance, Strategic Philanthropy, and Public Policy. Business Horizons, 42(3), 57-62.

Hess, D., Rogovsky, N., \& Dunfee, T. W. (2002). The next wave of corporate community involvement: Corporate social initiatives. California Management Review, 44(2), 110-125.

Hogarth, K., Hutchinson, M., \& Scaife, W. (2018). Corporate Philanthropy, Reputation Risk Management and Shareholder Value: A Study of Australian Corporate giving. Journal of Business Ethics, 151, 375-390.

Kasper, G., \& Fulton, K. (2006). The Future of Corporate Philanthropy: A Framework for Understanding Your Options. Retrieved February 02, 2020, from http://www.monitorinstitute.com/downloads/what-we-think/co rporate-philanthropy/Future_of_Corporate_Philanthropy.pdf.

Lessa, C., \& Rossetti, F. (2016). O futuro da filantropia no Brasil. Retrieved February 15, 2020, from https://gife.or g.br/artigo-o-futuro-da-filantropia-no-brasil-11794.asp. 
Livia Menezes Pagotto, et al. The Relation Between Corporate Philanthropy and Territorial Developm...

Liket, K., \& Maas, K. (2015). Strategic Philanthropy: Corporate Measurement of Philanthropic Impacts as a Requirement for a "Happy Marriage" of Business and Society. Business \& Society, 55(6), 889-921.

Logsdon, J. M., \& Wood, D. J. (2002). Business Citizenship: From Domestic to Global Level of Analysis. Business Ethics Quarterly, 12(2), 155-87.

Matten, D., \& Crane, A. (2005). Corporate citizenship: toward and extended theoretical conceptualization. Academy of Management Review, 30(1), 166-179.

Moffat, F. \& Zhang, A. (2014). The paths to social licence to operate: An integrative model explaining community acceptance of mining. Resources Policy, 39 (2014), 61-70.

Moon, J., Crane, A., \& Matten, D. (2005). Can Corporations Be Citizens? Corporate Citizenship as a Metaphor for Business Participation in Society. Business Ethics Quarterly, 15(3), 429-453.

Nogueira, F. A., \& Schommer, P. C. (2009). Quinze anos de Investimento Social Privado no Brasil: conceito e práticas em construção. Proceedings of the Encontro - ANPAD, 33. (pp. 1-16).

Oliva, R. (2016). Alinhamento entre o investimento social privado e o negócio. São Paulo: GIFE.

Pagotto, L. M., Belinky, A., Macedo, F., \& Yamahaki, C. (2016). Entre o público e o privado: caminhos do alinhamento entre o investimento social privado e o negócio. São Paulo: FGVces.

Patton, M. Q. (2001). Qualitative Research \& Evaluation Methods. (3rd ed.). Sage Publications: Thousand Oaks, California.

Porter, M. E., \& Kramer, M. R. (2002). The Competitive Advantage of Corporate Philanthropy. Harvard Business Review, 80(12), 56-69.

Porter, M. E., \& Kramer, M. R. (2011). Creating shared value. Harvard Business Review, 89(1), 62-77.

Rehbein, K., \& Schuler, D. A. (2013). Linking Corporate Community Programs and Political Strategies: A ResourceBased View. Business \& Society, 54(6), 794-821.

Romeo, L. (2013). Decentralizing for Development: The developmental potential of local autonomy and the limits of politics-driven decentralization reforms. In J. Öjendal, and A. Dellnäs, The Imperative of Good Local Governance: Challenges for the Next Decade of Decentralization. United Nations University Press.

Rossetti, F. (2010). Da filantropia ao investimento social privado. In F. Rossetti (ed.), Filantropia Global, (pp. 265-276). GIFE, São Paulo.

Saiia, D. H., Carroll, A. B., \& Buchholtz, A. K. (2003). Philanthropy as strategy. Business \& Society, 42(2), 169-201.

Saquet, M. (2009). Por uma abordagem territorial. In M. Saquet, \& E. Sposito. Territórios e territorialidades: teorias, processos e conflitos. (pp. 73-95). São Paulo: Expressão Popular.

Sasse, C. M., \& Trahan, R. T. (2007). Rethinking the new corporate philanthropy. Business Horizons, 50(1), 29-38.

Seitanidi, M. M., \& Ryan, A. (2007). A critical review of forms of corporate community involvement: from philanthropy to partnerships. International Journal of Nonprofit and Voluntary Sector Marketing, 12(3), 247-266.

Torre, A., \& Wallet, F. (2015). Towards new paths for regional and territorial development in rural areas. European Planning Studies, 23(4), 650-677. doi:10.1080/09654313.2014.945812

Van der Voort, J., Glac, K., \& Meijs, L. (2009). "Managing" Corporate Community Involvement. Journal of Business Ethics, 90(3), 311-329.

Vveinhardt, J., \& Zygmantaite, R. (2015). Impact of Social Context on Strategic Philanthropy: Theoretical Insight (June 18, 2015). Jolita Vveinhardt and Rasa Zygmantaite. Procedia - Social and Behavioral Sciences, 214, 1165-1173.

Waddock, S. A. (2008). Corporate responsibility/corporate citizenship: the development of a construct. In A. G. Scherer and G. Palazzo (eds.), Handbook of Research on Global Corporate Citizenship (pp. 50-73). Edward Elgar, Cheltenham and Northampton.

Waddock, S. A., \& Boyle, M-E. (1995). The Dynamics of Change in Corporate Community Relations. California Management Review, 37(4), 125-140. 
Administração Pública e Gestão Social, 2022, vol. 14, núm. 1, Enero-Marzo, ISSN: 2175-5787

Wood, D. J., \& Jones, R. E. (1995). Stakeholder mismatching: A theoretical problem in empirical research on corporate social performance. International Journal of Organizational Analysis, 3(3), 229-267. 